\title{
Fungus-growing ants (Hymenoptera: Formicidae) on Santa Catarina Island, Brazil: patterns of occurrence
}

\author{
Benedito Cortés Lopes ${ }^{1} \&$ Harold Gordon Fowler ${ }^{2}$ \\ 1 Departamento de Ecologia e Zoologia, Centro de Ciências Biológicas, Universidade Federal de Santa Catarina, \\ C.P. 476, Florianópolis, SC, Brazil, CEP 88010-970, Fax (048) 3319672, e-mail: bclopes@ccb.ufsc.br; \\ 2 Departamento de Ecologia, Instituto de Biociências, UNESP, Rio Claro, SP, Brazil, CEP 13506-900, \\ e-mail: hgfowler@rc.unesp.br
}

Received 19-VII-1999 Corrected 18-I-2000 Accepted 4-II-2000.

\begin{abstract}
A taxonomic survey on fungus-growing ants (Attini) was made at 14 beaches on Santa Catarina Island (SC), Brazil. The samplings were manual, in soil or litterfall, in the following habitats: sandy beach, herbaceous vegetation and shrubby vegetation. From 12 species of Attini (ten of Acromyrmex Mayr and two of Cyphomyrmex Mayr), the most frequent were Cyphomyrmex morschi Emery and Acromyrmex crassispinus Forel, collected, respectively, on eight and ten of the monitored beaches. Altogether, Sorensen's similarity coefficients were high (range: $0.59-0.80$ ), in spite of the lower numbers of ant species on sandy beaches.
\end{abstract}

Key words: Fungus-growing ants, beaches, Santa Catarina Island, Brazil, Attini.

The tribe Attini, that comprises the fungus-growing ants -and the more specialized leaf-cutters- are restricted to the New World, the majority of species recorded from the Nearctic region (Weber 1982, Fowler 1983, Mayhé-Nunes 1995).

Ferreira-Lima (1945) lists six species of Acromyrmex and one of Atta Fabricius for Santa Catarina State. Among these, only Acromyrmex disciger Mayr and Acromyrmex laticeps Emery are mentioned as occurring on Santa Catarina Island. Recently, Bonnet and Lopes (1993) recorded four species of Attini (Acromyrmex niger (Fr. Smith), Acromyrmex striatus (Roger), Cyphomyrmex morschi and Trachymyrmex iheringi (Emery)) at Joaquina Beach on Santa Catarina Island.

This paper measures species coexistence for attine ants in Santa Catarina Island. We carried out the following: a) a taxonomic inventory of species of Attini at some beaches on
Santa Catarina Island $\left(27^{\circ} 10^{\prime}\right.$ and $27^{\circ} 50^{\prime} \mathrm{S} ; 48^{\circ}$ $25^{\prime}$ and $48^{\circ} 35^{\prime} \mathrm{W}$ ) and $\mathrm{b}$ ) an association of species with habitats at the beaches (on the sand, and in both herbaceous and shrubby vegetation).

The samplings were all manual, in soil or litterfall, because the attine ants were not attracted by the usual baits (honey, sardine or tuna paste) (Silva and Lopes 1997). These samplings were done from 03.14.1996 to 06.07.1996 at 14 beaches on Santa Catarina Island. The beaches "profiles" varied from zero to five meters above the sea level. The main vegetation species are: Blutaparon portulacoides (St.-Hil.) Mears (Amaranthaceae), Oxypetalum cf. banksii R. \& S. (Asclepiadaceae), Conyza cf. canadensis (L.) Cronq., Porophylum ruderale (Jacq.) Cass. (both Compositae), Ipomoea imperati (Vahl) Grisebach, Ipomoea pes-caprae (L.) R. Brown (both Convolvulaceae), Remiria maritima Aubl. (Cyperaceae), Panicum racemosum Spr., Pas- 
TABLE 1

Species of Attini recorded at the 14 beaches sampled on Santa Catarina Island, Brazil.

$\begin{array}{lccc}\text { Ant taxon } & \text { Sandy beach } & \text { Herbaceous vegetation } & \text { Shrubby vegetation } \\ \text { Acromyrmex crassispinus } \text { (Forel) } & \mathrm{D}, \mathrm{T} & \mathrm{M}, \mathrm{JI}, \mathrm{F}, \mathrm{G}, \mathrm{CBS}, \mathrm{A}, \mathrm{C} & \mathrm{BL}, \mathrm{D}, \mathrm{M}, \mathrm{JI}, \mathrm{G}, \mathrm{T} \\ \text { A. } \text { disciger } \text { (Mayr) } & - & \mathrm{BN} & - \\ \text { A. } \text { fracticornis } \text { (Forel) } & - & \mathrm{JI}, \mathrm{A} & \mathrm{BL}, \mathrm{G} \\ \text { A. } \text { hispidus fallax Santschi } & \mathrm{D}, \mathrm{JI} & \mathrm{BL}, \mathrm{D}, \mathrm{PS} & \mathrm{BL} \\ \text { A. laticeps } \text { (Emery) } & - & \mathrm{J} & \mathrm{BL} \\ \text { A. } \text { niger } \text { (Fr. Smith) } & - & \mathrm{C} & - \\ \text { A. } \text { rugosus } \text { (Fr. Smith) } & \mathrm{D} & \mathrm{D}, \mathrm{PS} & \mathrm{D}, \mathrm{PS} \\ \text { A. } \text { striatus } \text { (Roger) } & \mathrm{BL} & \mathrm{G}, \mathrm{A} & \mathrm{BL}, \mathrm{G}, \mathrm{A} \\ \text { A. } \text { subterraneus } \text { (Forel) } & - & \mathrm{BL}, \mathrm{PS} & \mathrm{M}, \mathrm{PS} \\ \text { Acromyrmex } \text { sp. } & - & \mathrm{PS} & - \\ \text { Cyphomyrmex } \text { morschi } \text { Emery } & \mathrm{D}, \mathrm{JI} & \mathrm{BL}, \mathrm{D}, \mathrm{M}, \mathrm{JI}, \mathrm{G}, \mathrm{CBS}, \mathrm{SAL}, \mathrm{PS} & \mathrm{BL}, \mathrm{D}, \mathrm{M}, \mathrm{JI}, \mathrm{G} \\ \text { Cyphomyrmex sp. } & - & \text { SAL, C, J, PS } & -\end{array}$

Codes: $\mathrm{A}=$ Armação, $\mathrm{BL}=$ Barra da Lagoa, $\mathrm{BN}=$ Beiramar Norte, $\mathrm{C}=$ Cacupé, $\mathrm{CBS}=$ Caieira da Barra do Sul, $\mathrm{D}=\mathrm{Da}-$ niela, $\mathrm{F}=$ Forte, $\mathrm{G}=$ Galheta, $\mathrm{J}=$ Joaquina, JI = Jurerê Internacional, $\mathrm{M}=$ Moçambique, $\mathrm{PS}=$ Pântano do Sul, SAL = Santo Antônio de Lisboa e T = Toló.

(both Gramineae), Canavalia rosea (Sw.) DC., Dalbergia ecastophyllum (L.) Taub. (both Leguminosae), Dodonaea viscosa (L.) Jacq. (Sapindaceae) and Hydrocotyle bonariensis Lam. (Umbelliferae) (Bresolin 1979, Castellani et al. 1999). Each beach was examined for at least three hours in the above-mentioned habitats. The voucher specimens were deposited in the reference collection of the Departamento de Ecologia e Zoologia, CCB/UFSC. The taxonomic identification follows Gonçalves (1961), Kempf (1964), Fowler (1988) and Bolton (1994).

For the faunistic comparison in the three beach habitats, Sorensen's similarity coefficient was used (Krebs 1989).

We recorded 12 species of Attini, of which ten were Acromyrmex and two Cyphomyrmex (Table 1).

Only five species were actually present on the sand itself. This is a restricted location for foraging because of vegetation escarcity. In contrast, the beaches with herbaceous vegetation had all 12 species. This is particularly consistent with Acromyrmex preference for open habitats
(Fowler 1983, Farji-Brener and Ruggiero 1994).

The values for Sorensen's similarity coefficients were 0.59 (sand and herbaceous vegetation), 0.77 (sand and shrubby vegetation) and 0.80 (herbaceous vegetation and shrubby vegetation). These high coefficients reflect the fact that all the species that occur on sand, also nest in sections with herbaceous and shrubby vegetation (Table 1).

The number of Acromyrmex species (ten) is high in comparison with other studies in coastal Brazil: three species were recorded by Gonçalves and Nunes (1984), two by Bonnet and Lopes (1993) and two by Fowler and Pesquero (1996). Acromyrmex fracticornis (Forel) and Acromyrmex rugosus (Fr. Smith) are new records for Santa Catarina State, according to the reference list of Della Lucia et al. (1993). Acromyrmex crassispinus was the most frequent species, being collected on ten of the 14 beaches, even at the tideline, while foraging among organic material. This species is referred to by Gonçalves (1961) as the "commonest leaf-cutting ant in southern Brazil". 
Most Cyphomyrmex were C. morschi. This species commonly appears in other coastal regions inventories (Kempf 1964, Bonnet and Lopes 1993).

In regard to future work, we suggest an increase in collections at other beaches on Santa Catarina Island as well as collections during other periods of the year.

\section{REFERENCES}

Bolton, B. 1994. Identification Guide to the Ant Genera of the World. Harvard University, Cambridge, Massachusetts. 222 p.

Bonnet, A. \& B. C. Lopes. 1993. Formigas de dunas e restingas da Praia da Joaquina, Ilha de Santa Catarina, SC (Insecta: Hymenoptera). Biotemas 6: 107-114.

Bresolin, A. 1979. Flora da restinga da Ilha de Santa Catarina. Ínsula 10: 1-54.

Castellani, T. T., C. A. Caus \& S. Vieira. 1999. Fenologia de uma comunidade de duna frontal no Sul do Brasil. Acta Bot. Bras. 13: 99-114.

Della Lucia, T. M. C., H. G. Fowler \& D. D. O. Moreira 1993. Espécies de formigas cortadeiras no Brasil, p. 26-31. In: T. M. C. Della Lucia (ed.). As formigas cortadeiras. Sociedade de Investigações Florestais \& Universidade Federal de Viçosa, Viçosa, Brasil.

Farji-Brener, A. G. \& A. Ruggiero. 1994. Leaf cutting ants (Atta and Acromyrmex) inhabiting Argentina: patterns in species richness and geographical range sizes. J. Biogeogr. 21: 391-399.

Ferreira-Lima, A. D. 1945. Insetos fitófagos de Santa Catarina. Bol. Fitossanit. 2: 233-251.
Fowler, H. G. 1983. Latitudinal gradients and diversity of the leaf-cutting ants (Atta and Acromyrmex) (Hymenoptera: Formicidae). Rev. Biol. Trop. 31: 213-216.

Fowler, H. G. 1988. Taxa of the neotropical grass-cutting ants, Acromyrmex (Moellerius) (Hymenoptera: Formicidae: Attini). Científica 16: 281-295.

Fowler, H. G. \& M. A. Pesquero. 1996. Ant assemblages (Hymenoptera: Formicidae of the Ilha do Cardoso State Park and their relation with vegetation types. Rev. Brasil. Biol. 56: 427-433.

Gonçalves, C. R. 1961. O gênero Acromyrmex no Brasil (Hymenoptera: Formicidae). Studia Ent. 4: 113-180.

Gonçalves, C. R. \& A. M. Nunes. 1984. Formigas de dunas e restingas do Brasil, p. 93-102. In: L. D. Lacerda, D. S. D. Araujo, R. Cerqueira \& B. Turcq (eds.). Restingas: origem, estrutura, processos. Universidade Federal Fluminense, Niterói, Brasil.

Kempf, W. W. 1964. A revision of the Neotropical fungusgrowing ants of the genus Cyphomyrmex Mayr. Part 1: Group of strigatus Mayr (Hym., Formicidae). Studia Ent. 7: 1-44.

Krebs, C. J. 1989. Ecological Methodology. Harper \& Row, New York, $654 \mathrm{p}$.

Mayhé-Nunes, A. J. 1995. Filogenía de los Attini (Hym., Formicidae): un aporte al conocimiento de las hormigas fungívoras. Ph.D. Thesis, Universidad Simón Bolívar, Caracas, Venezuela.

Silva, R. R. da \& B. C. Lopes. 1997. Ants (Hymenoptera: Formicidae) from Atlantic rainforest at Santa Catarina Island, Brazil: two years of sampling. Rev. Biol. Trop. 45: 1641-1648.

Weber, N. A. 1982. Fungus ants, p. 255-363. In: H. R. Hermann (ed.). Social Insects, Academic, New York, vol. 4 